\title{
Why Do Students Engage in Examination Malpractice? The University for Development Studies Experience
}

\author{
John Dadzie Thompson \\ Faculty of Education, University for Development Studies, Tamale Campus, Ghana \\ Gilbert Ansoglenang (Corresponding author) \\ Office of the Principal, University for Development Studies, Navrongo Campus, Ghana \\ E-mail: ansogle68@yahoo.com
}

\begin{abstract}
Suuk Laar
Institute for Interdisciplinary Research and Consultancy Services, University for Development Studies, Tamale, Ghana
\end{abstract}

Received: July 30, 2019 Accepted: August 22, $2019 \quad$ Published: August 24, 2019

doi: 10.5296/ire.v7i2.15330 URL: https://doi.org/10.5296/ire.v7i2.15330

\begin{abstract}
Any form of examination malpractice is unacceptable, fraudulent, and signifies an act of academic dishonesty with significant punitive consequences. This paper investigated the reasons why students engage in examination malpractice during examinations at the University for Development Studies (UDS). The study adopted a cross-sectional survey design for this research and targeted undergraduate students of the Tamale Campus of the UDS. Simple random sampling technique was used to select 278 out of a total student population of 6,729 for the study. They responded mainly to questionnaire and a few open ended questions to provide the needed data for analysis. The findings suggest that (i) smuggling of prepared notes on pieces of papers (foreign material) into the examination hall, (ii) writing of examination answers on palms, thighs and other body parts, and (iii) communication by seeking for answers from colleagues are the three topmost forms/methods students engage to cheat during examinations. The desire to obtain good grades just as the more intelligent students pushes some students to cheat during examinations. The introduction of scanners and e-search software, the spacing of sitting arrangements, installation of Closed Circuit Television (CCTV)
\end{abstract}


cameras in large examination halls may help curb cheating.

Keywords: Examination malpractice, Cheat, Examination, Students

\section{Introduction}

The rise in examination malpractice cases across the education system in Ghana in recent times is drawing significant national attention, particularly at the basic and senior high school level though there exist some examination malpractice tendencies at the tertiary education level as well. There are many ways of assessing students, one of which is by examination. Globally, the key reason for examination is to determine students' level of understanding, after undertaking a course. Accordingly, examination remains one of the most acknowledged approaches in assessing how much one has learned and also in finding out the extent to which the objectives and goals of the course have been attained. According to Makaula (2018), students' performance in examinations forms the basis of important decisions about their educational and vocational futures. The author, however, acknowledge that the use of examination in selecting students for further education or employment places a heavy burden on the education system. Students can be assessed depending on their grade, however, because of the importance attached to examination; issues concerning examinations should be carefully thought through to make the outcomes more credible and acceptable within the wider society. Perhaps, it is for this reason that Phiri and Nakamba (2015) argue that there is the need to put in place measures to ensure examinations are conducted in a manner that sustains confidence and credibility. It is generally believed that education has a positive impact on students, and examination outcome is an appropriate measure of the extent to which students have acquired knowledge to be better citizens in society.

According to Asante-Kyei and Nduro (2014), education is one of the key conduits to the socio-economic development of every nation. In their view, an examination is one of the assessment tools used to periodically assess and evaluate products of the educational system. Education contributes towards building people's abilities, competencies and job readiness skills appropriate for the job market. This makes examination an essential function in the education system. Asante-Kyei and Nduro (2014) observed that examinations continue to remain one of the most appropriate tools for evaluating and assessing what students have learnt. They argued that any action that is taken during examinations can act as a threat to the legitimacy, dependability and genuineness of the grades besides the certificates obtained (Asante-Kyei \& Nduro, 2014). In recent times, because of the competitive nature of the job market coupled with societal expectations, the pressure is often mounted on students to do all it takes to pass their examinations. The ultimate desire to pass examinations, therefore, makes some students to resort to dubious means.

Though limited studies have been conducted in this area within the Ghanaian context, several studies point to the fact that when students feel and believe that they can indulge in examination malpractice to get good grades and go unnoticed, it increases the likelihood of others engaging in the act. Similarly, when the punitive measures for engaging in examination malpractice is considered by students to be mild or minor, they are likely to engage in such acts (Miranda \& Freire, 2011; Asante-Kyei \& Nduro, 2014). With the mindset to engage in examination malpractice, students are likely to neglect their books with the hope that they can outsmart invigilators and examination officials during an examination. It is for 
this reason that many have condemned the act because instead of learning to get the good grades, students choose not to learn but still want to pass with the needed grades. Examination malpractice has a compounding effect in the sense that students who are successful in engaging in examination malpractices also demoralize other students who do not engage in such acts. As studies have shown, examination malpractice has been in existence for many years, particularly in some collectivist cultural orientation where they glorify qualifications at the expense of capabilities. Writing on how examination malpractices could influence the educational outcome of pupils in high schools in the Kitwe District of Zambia, Phiri and Nakamba (2015) acknowledged that many institutions of learning and examining bodies encounter issues about examination malpractice. It is becoming an acceptable practice and, in some instances, parents have been part of such unethical practices to ensure they secure better opportunities for their children.

In today's world, examination malpractice is becoming an act that is gaining notoriety in many African societies. This act which is publicly labeled as intellectual dishonesty is exhibited by most candidates despite the various punitive measures put in place. Nevertheless, the credibility of every nation's educational system depends on the validity and reliability of the examination process. It is, therefore, important for administrators of examining bodies to make a conscious effort towards curtailing the situation since its consequences are grievous. For this reason, Hang'andu (2005) cited in Phiri and Nakamba (2015) suggests that the implication is not only dire for the education system but rather for students, teachers, parents, and the school and more broadly the nation as a whole.

\section{Statement of the Problem}

In the Ghanaian context, the media has been highlighting impersonation and leakage of examination questions as being a recurring act generally associated with the West African Examination Council (WAEC), which is the examining body for basic, senior high and technical school education in the country. The evidence points to collusion between students, parents and school authorities being perpetrators of malpractices. Many students have their results either cancelled or withheld until investigations are carried out by the examining body. In other instances, the examining body is compelled to reorganize the whole examination again. Our curiosity and interest heightened when media reports suggested that examination malpractice was not only endemic at the basic and senior high school level but was also gaining momentum at the tertiary level. The literature highlights varied reasons underpinning examination malpractice. These include societal demands for good grades over skills, parental pressures and the limited space for students in the education system push students to engage in such acts to get access to the education system, and to satisfy employers' preference of good grades as a measure of better workforce, etcetera. On the part of the students, the fear of failure or scoring poor grades drive them to engage in examination cheating (Phiri \& Nakamba, 2015; Achio et al., 2012).

At a personal level, based on our interactions with a cross-section of students on the various campuses of the University, we observed that a number of students spend much of their time whilst in school, on non-academic activities such as politics, religious activities, entertainment, sporting activities and other social events, all to the detriment of their studies. Our contention here is not to argue that students should not engage in non-academic activities. We support 
holistic education which includes non-academic activities, but we argue that many of the students have failed to balance their time and effort on academic with non-academic activities. In most instances, students have prioritized non-academic activities over their academic work leading to the failure to attend lectures, write quizzes or mid-trimester examinations, and submit assignments on due dates.

We further acknowledge the fact that different students have different capabilities and potentials as some may be naturally gifted, brilliant and academically-endowed whilst others may be average or weak students and will require more attention and time to be able to read and demonstrate understanding. It is observed that in trying to cope with the naturally gifted and brilliant students, the average and weak students are likely to engage in examination malpractice to score good grades. It is important to acknowledge here that we are not by any chance arguing that brilliant students do not engage in examination malpractice; however, we argue that the propensity for weak students to engage in examination malpractice is higher compared to brilliant students, all things being equal. Some of the students also embrace the idea that once other students were able to use corrupt means to pass their examinations, earn a certificate and got employed; cutting corners to pass their examination may be a possibility. Accordingly, they may be tempted to engage in such dishonest practices. This perception adopted by these students could be a disincentive to studying hard to acquire the needed knowledge to be able to pass the examinations. With the mindset that the road to success could be attained by dishonest means, they care less about the impact of such acts on the wider society. Once they go through the education system successfully using such means, other students may be motivated to resort to similar dishonest acts and practice. In light of this, our paper set out to examine the following research questions:

(i) How do students perceive and understand examination malpractice?

(ii) Why do students engage in examination malpractice?

(iii) What are the common forms of examination malpractice in a university setting?

\section{Literature Review}

An examination is defined by Balogun (1999) as the extent to which a candidate can master a subject matter in a particular field of study within a given time. He also terms examination as a method used to assess how students answer questions or undertake practical exercise to know the worth of their understanding acquired in the particular subject within a given period. For Hornby (1995), an examination is a formal test organized for somebody in a particular subject to answer questions or undertakes practical exercises to ascertain his or her knowledge. Generally, examinations have a direct component of formal learning and serve particular purposes in the education system of a given nation (Edokpa, 1998; Phiri \& Nakamba, 2015). Examinations help in assessing the learners' knowledge, skills, abilities, and competencies (Edokpa, 1998). Several authors (Oduwaiye, 2014; Oko \& Adie, 2016) have argued that examination is a structured assessment method which helps one to know the skills acquired by the individual. This, they argue can be done by presenting the individual with a series of questions or tasks within a stipulated time.

Exploring the perceived causes and forms of examination malpractice in Malawi, Makaula (2018) proclaims that the exact date that examination malpractice found its root in human 
communities is not known. However, he concludes that the evidence of increasing episodes of examination malpractices at all levels of the education system abounds globally. It has been reported that examination malpractice was first known to have existed in the Chinese civil service examinations, where examinations were given in individual cubicles to prevent examinees from looking at the test papers of others (Kibler, 1993; Makaula, 2018). Kibler (1993) argued that there were strict precautions and regulations which included the death penalty for both the guilty students and the examiners, and in the process, examiners searched for notes before entering the cubicles. A study on high school students in the United States by McCabe (2005) cited in Makaula (2018) revealed that there were high levels of students cheating during examinations. Eckstein (2003) also established that $75-80 \%$ of students confessed of having copied from others or having taken prohibited materials into the examination hall. Writing on "examination malpractice in India, Maheshwari (2011) argued that, examination malpractice was seen as a form of corruption. The author further noted that the country criticized persons for committing virtues but celebrated and rewarded that of vices (social, economic, political, religious and educational). Khan et al. (2012) also reported that examination malpractice in Secondary School Certificate Education in Pakistan was so endemic that it could not be eliminated.

Makaula (2018) affirms that the first reported case of examination malpractice in Africa was documented in Nigeria during the Cambridge School Certificate Examination in 1994 when the questions have seeped to candidates. According to him, examination malpractice in Nigeria became prevalent and legitimated among students, after the promulgation of Decree 20 of 1984 by the Federal government and some regarded the practice as a normal process of passing examinations. Kithuka (2004) also postulated that examination malpractice in Kenya reached disturbing dimensions such that even when stakeholders in the educational sector and the government made attempts to curtail the situation, it did not materialize. A study by Munachonga (2014) revealed that occurrences of examination malpractice had in recent times taken a precarious and worrying turn because parents, teachers, supervisors and even school managers were directly involved. Mashananyare and Chinamasa (2014) found that three Advanced levels (A-level) examination papers had to be cancelled in Egypt amid concerns that the content could have leaked out. This followed an allegation that the papers were mixed with batches of past examination papers requested from Edexel GCE (Britain) to schools in Egypt for pupils to use in revision sessions. Mashananyare and Chinamasa (2014) noted that examinations were a nightmare in Zimbabwe and accordingly, asserted that examinations may have been leaking, though it received little publicity, before the localization of examinations.

For Obudigha (2010) cited in Ndifon and Cornelius-Ukpepi (2014), as the years pass by, examination malpractice at the primary school level has taken a different dimension and that the most common practice range from giraffing. The author added that cheating in examinations has taken a different dimension where pupils have now resorted to writing materials and information that would aid them in the examination, on their body parts. He added that others also write information on chairs, tables, and walls of examination halls. An emerging form is where some pupils' carry foreign materials into the examination halls, with educational stakeholders providing them with assistance. Irregular activities take place both inside and outside of examination halls, and that impersonation, leakage of question papers 
and electronically assisted malpractices are all now rife (Obudigha, 2010). In their work on examination malpractice among polytechnic students, Lawal et al. (2015) argue that any wrongdoing or illegal activity that one takes for his or her benefit constitutes misconduct. They also argue that students on their own or with the connivance of persons associated with the examination body can cheat prior to the examination, in the course of the examination and after the examination, to get undeserving grades. Thus, for Onah (2010) cited in Lawal et al. (2015), cheating in an examination is any foul means adopted by students which makes the result and assessment unusable.

It has been argued that examination malpractice is any form of fraudulent activity by a candidate with the prime objective of getting a better result than his or her own actual intelligence and performance (Umaru, 2005; Lawal et al., 2015). Makaula (2018) asserts that the act of examination malpractice is a threat to the legality and dependability of the educational system, and also threatens the sincerity of the examination. It is important to know that examination malpractice does not only harm both the moral and intellectual development of the student but also damages the authority of those responsible for conducting the examinations (Makaula, 2018). Nwana (2000) describes examination malpractice as the immense and unparalleled misapplication of rules and regulations relating to all forms of examinations, be it internal or public. In his view, it begins with the process of putting the questions together through to the administering of the examination, marking of scripts, rating, and issuing of the certificate. For Nwahunanya (2004), any act of aiding or abetting by an examination official with the intent of making a student excel in an examination, without having to rely completely on his or her independent capability or resources, constitutes examination malpractice. Phiri and Nakamba (2015) suggest that examination malpractice may include imitation, seepage, exchange of scripts, carrying of answer writings into the examination room and direct replication. The authors further argue that examination malpractice includes the forging of results and certificates and the verbal or physical assault on examination administrators.

Makaula (2018) found that smuggling of foreign materials into the examination hall is, perhaps, the most common method of examination malpractice. Clabaugh and Rozycki (2009) lamented that misconduct and acts of deceit during examinations was growing in complexity and ranged from candidates carrying unapproved items to using technology in the examination halls. Nnam and Inah (2015), found out from their studies that smuggling of foreign materials, the use of mobile phones and other electronic devices were common forms of examination malpractices used by students in recent times. Clabaugh and Rozycki (2009) further noted that female students scribble notes on their thighs and read during examinations, trusting that male invigilators will not dare watch their thighs for fear of being tagged for sexual harassment. On their part, Suleman et al. (2015) reported that candidates carry unlawful items including handy scripts and electronic devices to examination centers with the aim of cheating during the examination.

Oko and Adie (2016) revealed from their findings that copying someone's work by stretching the neck otherwise termed as 'giraffing' was used frequently to cheat during examination among students of Cross River University of Technology. This was followed by collusion where brilliant students sat in the middle to assist weak students in the examination hall. 
Cheating via electronic means such as using mobile phones and other devices for storing information ranked third, while smuggling of foreign materials into the examination halls ranked fourth. Nnam and Inah (2015) opined that some common forms of examination malpractices at the Ebony State University in Nigeria were for candidates to smuggle unlawful tiny pieces of papers into the examination hall and use other electronic devices such as mobile phones to cheat during examinations.

Boakye (2015) states that examination malpractice is gradually turning out to be a normal practice in society, and the nation as a whole. He asserts that because students are ignorant, they engage in examination malpractices without considering the consequences of their actions. He further pointed out that students, who do not prepare adequately for the examinations and on time, are those who are usually found culpable of attempting to smuggle foreign materials into the examination hall.

Tambawal (2013) argues that any erroneous planned action geared towards changing the rules governing examination which could ultimately give a contender undue advantage over his or her counterparts constitutes examination malpractice. He further notes that examination malpractice introduces inequity into the examination system and accordingly, identifies smuggling of unacceptable items into the examination center, copying, intimidation, leakage, impersonation, as well as external assistance as forms of cheating in examination. The effects of examination malpractice are awful, and as he underscores, when less intelligent students cheat or indulge in examination malpractice to get a 'bite at the cherry', it serves as a disincentive to the effort, demotivates, and lowers the confidence level of the relatively brilliant students (Tambawal, 2013). He argues that it tends to lure students into areas perceived to be misconduct such as prostitution and armed robbery. On the one hand, some recalcitrant female students may trade sex in exchange for high scores, and their male counterparts may also resort to stealing/robbing to earn income to pay for scores.

According to Uzochukwu (2018), any student who is caught to have been involved in examination malpractice devalues his or her person. He argues that such a student indirectly portrays to the world that he/she cannot do without the help of someone. The author argues that examination malpractice is unacceptable because candidates do not work hard to make the grades but rather use falsified and fraudulent means to obtain undeserving high marks. In his view, such students may not attach much seriousness to their studies because of the perception that they could always cheat to get good results. For Achio et al. (2012), the fear of abysmal performance or attaining low grades during examinations push students to indulge in examination malpractice. In their view, students who fail to prepare adequately for examinations try to cheat or cut corners to get good grades. Ndifon and Cornelius-Ukpepi (2014) hold a similar view as they argued that when students have the notion that they can indulge in examination malpractice to get high scores, they become reluctant to study or work hard in their studies.

The danger associated with examination malpractice is that culprits who get jobs because they had high scores and were selected over their counterparts, fail to perform on the job and are unable to deliver at the workplace. It is the view of Phiri and Nakamba (2015) that, examination malpractices are evil and have associated long-term effects including the production of individuals who are corrupt and lack the moral to criticize those who indulge in 
the malpractice. This is because they themselves benefitted from the practice to get to their present position and standing in society. Aullo (2004) agrees with this view by his assertion that examination malpractice had aided in the churning out of incompetent graduates by institutions of higher learning. Similarly, Petters and Okon (2014) also postulated that students who cheat during examinations do not only have dubious characters but are also lazy. Accordingly, they recommended that such students needed to have a positive attitude towards studies if they want to attain academic successes. Elaborating on the consequences associated with examination malpractices Tambawal (2013) outlined the following:

Firstly, the products of examination malpractice are square pegs in round holes. For example, such products lack the requisite knowledge and experiences to enable them to perform their professional duties efficiently and effectively at the workplace. Also, they have limited confidence and academic morals because they cheated to excel. Thirdly, such beneficiaries of the malpractice end-up with unsatisfied visions in their selected professions. Besides, leaders who cheated to attain future leadership roles are more likely to be dishonest and unethical in their line of profession.

\section{Methodology}

\subsection{Research Design}

The study adopted a cross-sectional survey design for this research. This type of research involves collecting data through self-administered questionnaires or interviews and is particularly useful in describing the characteristics of a larger population. Another justification for using a cross-sectional survey design is that it is not costly to perform, and does not also require a lot of time when you are to perform it.

\subsection{Population and Sampling}

The target population for this study was undergraduate students of the Tamale Campus of the University for Development Studies. The researchers adopted the simple random sampling method in selecting 278 respondents out of the total student population of 6,729 (UDS, Academic Affairs Section, 2018). The reason for adopting a simple random sampling method is that it helps in eliminating sampling bias.

\subsection{Data Collection and Instruments}

A questionnaire was the main instrument of data collection, which was userd to gather the data. The questionnaire comprised mostly of close-ended and few open-ended questions to allow respondents to provide additional information. Section A of the questionnaire was on the acts that constitute examination malpractice. Section B solicited data on respondents' reason(s) for engaging in examination malpractice during an examination, whilst Section $\mathrm{C}$ solicited for information on the forms of examination malpractices. The questionnaire was designed using the 5-point Likert scale, where 1 is Strongly Disagree, 2 is Disagree, 3 is Not Sure, 4 is Agree, and 5 is Strongly Agree. The test and re-test technique was used to determine the dependability of the research tools.

\subsection{Data Analysis and Presentation}

Version 22 program of the Statistical Package for Social Sciences (SPSS) for Microsoft Windows was used to transcribe the data into text and analyzed. Descriptive Statistics including frequencies and percentages were used to present the results. 


\section{Results and Findings}

\subsection{Acts of Examination Malpractices}

We asked questions seeking to elicit answers from respondents on their understanding of what constitutes acts of examination malpractice.

Table 1. Responses to knowledge about examination malpractices and acts that may constitute a malpractice

\begin{tabular}{|c|c|c|c|c|c|c|c|}
\hline $\mathbf{S} / \mathbf{N}$ & Variable & Yes & $\%$ & No & $\%$ & Total & $\%$ \\
\hline 1 & $\begin{array}{l}\text { Have you ever heard of the term examination } \\
\text { malpractice }\end{array}$ & 257 & 92.7 & 21 & 7.6 & 278 & 100 \\
\hline 2 & $\begin{array}{l}\text { Have you ever seen or witness a colleague trying to } \\
\text { cheat in the examination hall }\end{array}$ & 174 & 62.6 & 104 & 37.4 & 278 & 100 \\
\hline 3 & $\begin{array}{l}\text { Do you think asking a friend for an eraser or to spell a } \\
\text { word for you during an examination constitute } \\
\text { cheating }\end{array}$ & 196 & 70.5 & 82 & 29.5 & 278 & 100 \\
\hline 4 & $\begin{array}{l}\text { Have you ever whispered to or communicated with a } \\
\text { colleague during an examination }\end{array}$ & 117 & 42.1 & 161 & 57.9 & 278 & 100 \\
\hline 5 & $\begin{array}{l}\text { Have you ever asked a colleague to assist you in any } \\
\text { form, during an examination }\end{array}$ & 83 & 29.9 & 195 & 70.1 & 278 & 100 \\
\hline 6 & $\begin{array}{l}\text { Have you ever carried an unauthorized material into } \\
\text { the examination hall }\end{array}$ & 21 & 7.6 & 257 & 92.4 & 278 & 100 \\
\hline 7 & $\begin{array}{l}\text { Do you think copying from prepared notes hidden on } \\
\text { one's body during an exams constitutes cheating }\end{array}$ & 250 & 89.9 & 28 & 10.1 & 278 & 100 \\
\hline 8 & $\begin{array}{l}\text { Have you ever seen a colleague in possession of } \\
\text { foreign material during an examination }\end{array}$ & 138 & 49.6 & 140 & 50.4 & 278 & 100 \\
\hline 9 & $\begin{array}{l}\text { Will you report a colleague in possession of foreign } \\
\text { material in the examination hall to an invigilator }\end{array}$ & 128 & 46.0 & 150 & 54.0 & 278 & 100 \\
\hline 10 & $\begin{array}{l}\text { Do you think the best way to pass an examination is } \\
\text { to cheat if one has not studied enough }\end{array}$ & 56 & 20.1 & 222 & 79.9 & 278 & 100 \\
\hline
\end{tabular}

Source: Survey Data, 2019.

The findings presented in Table 1 indicates that majority of the respondents representing $92.7 \%$ $(n=257)$ of the total population had a fair idea about what constitutes examination malpractice. About $89.9 \%$ responded in the affirmative that copying from prepared notes hidden on one's body constitutes cheating. The results also show that $70.5 \%(n=196)$ respondents think that asking a friend for an eraser or for him/her to spell a word for you in the examination hall constitutes cheating. Whilst our findings from Table 1 revealed that only 21 respondents 


\section{Macrothink

representing $7.6 \%$ responded that they had ever carried an unauthorized material with them into the examination hall, about $92.4 \%(n=257)$ of the population responded that they had never carried unauthorized material with them to the examination hall. Only $20 \%(n=56)$ of the respondents think that the best way to pass an examination is to cheat if one has not studied enough. On the contrary, $80 \%(n=222)$ of the total respondents think otherwise. This implies that students do not think that one has to be academically dishonest and also use dishonest and unacceptable means to pass an examination.

\subsection{Reason(s) Why Students Cheat During Examination}

This section of the study dealt with reasons why students cheat during examinations with the responses ranging from strongly disagree (SD) to strongly agree (SA). The findings indicate that respondents have adequate knowledge and different reasons why students cheat during examinations.

Table 2. Responses to the reason(s) why students cheat during examination

\begin{tabular}{|c|c|c|c|c|c|c|c|c|c|c|c|c|c|}
\hline $\mathbf{S} / \mathbf{N}$ & Variable & SD & $\%$ & D & $\%$ & NS & $\%$ & $\mathbf{A}$ & $\%$ & SAA & $\%$ & Total & $\%$ \\
\hline 1 & $\begin{array}{l}\text { Lack of } \\
\text { quality } \\
\text { teaching } \\
\text { makes } \\
\text { understanding } \\
\text { difficult }\end{array}$ & 54 & 19.4 & 38 & 13.7 & 52 & 18.7 & 86 & 30.9 & 48 & 17.3 & 278 & 100 \\
\hline 2 & $\begin{array}{l}\text { Some } \\
\text { students are } \\
\text { lazy and do } \\
\text { not study well } \\
\text { for the exams }\end{array}$ & 17 & 6.1 & 18 & 6.5 & 13 & 4.7 & 116 & 41.7 & 114 & 41.0 & 278 & 100 \\
\hline 3 & $\begin{array}{l}\text { Examination } \\
\text { pressure on } \\
\text { some students }\end{array}$ & 30 & 10.8 & 15 & 5.4 & 28 & 10.1 & 111 & 39.9 & 94 & 33.8 & 278 & 100 \\
\hline 4 & $\begin{array}{l}\text { Poor } \\
\text { attendance to } \\
\text { lectures by } \\
\text { some students }\end{array}$ & 20 & 7.2 & 11 & 4.0 & 19 & 6.8 & 115 & 41.4 & 113 & 40.6 & 278 & 100 \\
\hline 5 & $\begin{array}{l}\text { Desire to get } \\
\text { good grades } \\
\text { just as the } \\
\text { more } \\
\text { intelligent } \\
\text { students }\end{array}$ & 20 & 7.2 & 17 & 6.1 & 19 & 6.8 & 114 & 41.0 & 108 & 38.8 & 278 & 100 \\
\hline 6 & The & 36 & 12.9 & 33 & 11.9 & 54 & 19.4 & 77 & 27.7 & 78 & 28.1 & 278 & 100 \\
\hline
\end{tabular}


perception

that exams

questions are

out of scope

$7 \quad$ Some

17

students only

learn during

exams period

8 Inadequate

preparation

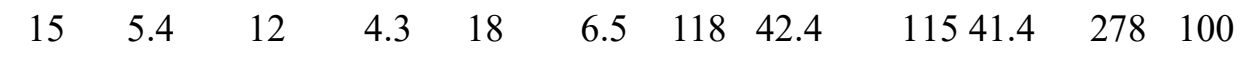

for the

examinations

by some

students

9 Eagerness to

pass the

$17 \quad 6.1 \quad 17$

6.124

$8.6 \quad 113 \quad 40.6$

$10738.5 \quad 278 \quad 100$

examinations

by all means

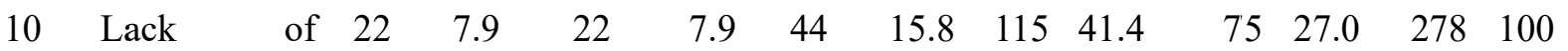

self-discipline

of some

students

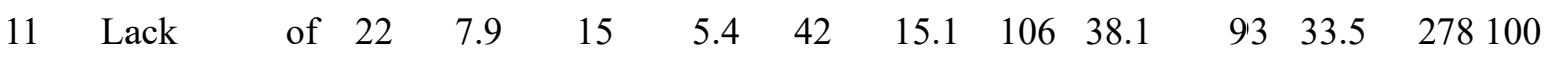

confidence in

some students

$12 \quad$ Difficulty in $\begin{array}{llllllllllll}25 & 9.0 & 17 & 6.1 & 34 & 12.2 & 114 & 41.0 & 8.8 & 31.7 & 278 & 100\end{array}$ memorizing

items studied

Source: Survey Data, 2019.

From the table above, about $42.1 \%(n=117)$ of the respondents and $43.2 \%(n=120)$ respectively strongly agree and agree with the assertion that eagerness to pass the examinations, by all means, accounted for the reasons why students cheat during examinations. Also, $41.4 \%$ $(n=115)$ and $42.4 \%(n=118)$ of the respondents respectively, strongly agree and agree that inadequate preparation for the examination by some students push them to cheat during examinations. Furthermore, 230 respondents consisting of 114 (41\%) and $116(41.7 \%)$, respectively, strongly agree and agree with the view that some students are lazy and do not study well for the examination, so they indulge in examination malpractices. It was also found that $113(40.6 \%)$ respondents and $115(41.4 \%)$ respondents respectively strongly agree and agree that poor attendance to lectures by some students push them to cut corners during an examination. Further, it was evident from the results that the desire to get good grades just as 


\section{Macrothink}

International Research in Education

ISSN 2327-5499

2019, Vol. 7, No. 2

the more intelligent students push some students to cheat during examinations, as revealed in our findings.

\subsection{Forms and Methods of Cheating in Examinations}

This section of the study dealt with the forms of cheating during examinations, with the factors ranging from smuggling of foreign materials into the examination hall to writing of answers on handkerchiefs being common.

Table 3. Responses to the forms that cheating can take during an examination

\begin{tabular}{|c|c|c|c|c|c|c|c|c|c|c|c|c|c|}
\hline $\mathbf{S} / \mathbf{N}$ & Variable & SD & $\%$ & D & $\%$ & NS & $\%$ & $\mathbf{A}$ & $\%$ & $\mathbf{S A}$ & $\%$ & Total & $\%$ \\
\hline 1 & $\begin{array}{l}\text { Smuggling of } \\
\text { foreign } \\
\text { materials into } \\
\text { the } \\
\text { examinations } \\
\text { hall }\end{array}$ & 26 & 9.4 & 19 & 6.8 & 14 & 5.0 & 123 & 44.2 & 96 & 34.5 & 278 & 100 \\
\hline 2 & $\begin{array}{l}\text { Writing of } \\
\text { examination } \\
\text { answers on } \\
\text { palms } \\
\text { thighs }\end{array}$ & 18 & 6.5 & 25 & 9.0 & 21 & 7.6 & 121 & 43.5 & 93 & 33.5 & 278 & 100 \\
\hline 3 & $\begin{array}{l}\text { Hiding pieces } \\
\text { of papers in } \\
\text { panties and } \\
\text { brassiere }\end{array}$ & 25 & 9.0 & 25 & 9.0 & 42 & 15.1 & 108 & 38.8 & 78 & 28.1 & 278 & 100 \\
\hline 4 & $\begin{array}{l}\text { Communication } \\
\text { or asking for } \\
\text { examinations } \\
\text { answers from } \\
\text { colleagues }\end{array}$ & 24 & 8.6 & 27 & 9.7 & 17 & 6.1 & 119 & 42.8 & 91 & 32.7 & 278 & 100 \\
\hline 5 & $\begin{array}{l}\text { Carrying } \\
\text { mobile phones } \\
\text { into the } \\
\text { examinations } \\
\text { hall }\end{array}$ & 35 & 12.6 & 30 & 10.8 & 17 & 6.1 & 117 & 42.1 & 79 & 28.4 & 278 & 100 \\
\hline 6 & $\begin{array}{l}\text { Carrying books } \\
\text { and handouts to } \\
\text { the } \\
\text { examinations } \\
\text { hall }\end{array}$ & 35 & 12.6 & 35 & 12.6 & 48 & 17.3 & 97 & 34.9 & 63 & 22.7 & 278 & 100 \\
\hline 7 & Pretend to use & 20 & 7.2 & 31 & 11.2 & 47 & 16.9 & 107 & 38.5 & 73 & 26.3 & 278 & 100 \\
\hline
\end{tabular}


the washroom

where they

copy

Stretching of

$29 \quad 10.4 \quad 23$

$8.3 \quad 54$

$19.4 \quad 111 \quad 39.9$

61

$21.9 \quad 278 \quad 100$

neck to copy

from colleagues

work

9 Use

of

$\begin{array}{lll}29 & 10.4 \quad 20\end{array}$

$7.2 \quad 24$

$8.6 \quad 116 \quad 41.7$

89

$32.0 \quad 278 \quad 100$

wristwatches to

cheat

10 Writing

$\begin{array}{lllll}25 & 9.0 & 29 & 10.4 & 56\end{array}$

$20.1 \quad 115 \quad 41.4$

answers on

handkerchiefs

Source: Survey Data, 2019

Table 3 shows that the three common forms/methods that students use to cheat during examinations are smuggling of foreign materials into the examination halls, writing of examination answers on palms, thighs and other body parts, and communication through asking for answers from colleagues. From the findings, 219 (78.7\%) respondents strongly agree and agree that smuggling foreign materials into the examination hall was a common form of cheating they have engaged in or seen colleagues engaged in during examination. Also, 214 (77\%) respondents strongly agree and agree that writing of examination answers on palms, thighs and other body parts is a form used to cheat during examinations. Furthermore, 210 (75.5\%) strongly agree and agree that communication by asking for support from colleagues is another form of cheating during examinations. The results also revealed that students use their wristwatches to cheat whilst others carry mobile phones into the examination hall to aid them to copy as shown in Table 3. Again, we observed from Table 3 that $205(73.7 \%)$ strongly agree and agree with the assertion that students use their wristwatches to cheat in examinations. About 196 (70.5\%) strongly agree and agree with the view that students carry mobile phones into the examination halls just to use them to cheat during examinations.

\section{Discussion}

The findings of this study show that majority of the respondents ( $n=257$ ) $92.7 \%$ of the total have a fair idea about acts of examination malpractices and also know what constitutes examination malpractice. A majority of the students $(n=222) 80 \%$ do not think that the best way to pass an examination is to cheat if one has not studied enough. This implies that there are still honest students out there who will not use deceitful and unacceptable means to get good grades even if they have not studied enough for an examination. The results further revealed that eagerness to pass examinations, by all means, pushes students to cut corners to make good grades. By using dishonest means and being academically dishonest, they are more likely to become unproductive at the workplace because they will lack the knowledge, skills, and attitude to be able to function effectively. These findings are consistent with prior literature. For 
example, Aullo (2004) lamented that institutions of higher learning keep producing graduates who are ineffectual because many students continue to cheat during examinations. It is astonishing to comprehend how a wristwatch could be used in cheating during examinations as our results show that students use digital wristwatches to cheat during examinations. This implies that students have now adopted a sophisticated means of cheating during examinations. The outcome of this finding is consistent with that of Makaula (2018) who argued that during each test session in Zambia, candidates invented different ways of cheating with some methods being so challenging and sophisticated that invigilators were unable to detect.

Our study further revealed that school children found to be lazy and do not study enough for a test choose to use false means to attain better results. This result is consistent with Petters and Okon's (2014) study. The authors observed that students who tends to cheat are either indolent or have suspicious characters. Accordingly, they recommended that students needed to have not only an affirmative self-concept but positive outlook towards schooling, and effective learning practices to enable them attain to higher academic laurels.

A good number of respondents $80 \%(n=222)$ strongly agree and agree with the view that the desire of less brilliant students to get good grades just as the more intelligent students push them to indulge in examination malpractice. This reaffirmed the work of Makaula (2018) who observed that some students are brilliant whilst others are naturally weak so in trying to cope along with the naturally brilliant students to get good grades, the academically weak ones involve themselves in examination malpractices. Similarly, Achio et al. (2012) noted that the utmost significant factor that pushes candidates to cheat during examination is the wish to pass by all means. Achio et al. (2012) argued that the root cause of students cheating during examination lies in their fear of getting low grades or outright failure. The authors added that there was a tendency for students who are ill-prepared for an examination to use fraudulent and dishonest means to get the desired grades. Our findings further revealed that $80 \%(n=228)$ of the respondents agreed that poor attendance to lectures by some students who may not have prepared adequately for the examinations resort to cheating. This finding is consistent with the findings of Munachonga (2014) where the author found that students who fail to prepare adequately for examinations consider cheating as the best alternative to use to pass.

Moreover, 219 respondents agreed that students smuggle foreign materials into the examination hall to enable them to cheat during examinations, whilst 196 of them also agreed that students carry mobile phones into the examination hall to cheat. These results were consistent and agreed with that of earlier researchers. For example, Nnam and Inah (2015) asserted that some common forms of examination malpractices at the Ebony State University in Nigeria were for candidates to smuggle unlawful tiny pieces of papers into the examination hall and use other electronic devices such as mobile phones to cheat during examinations. Suleman et al. (2015) also found out from their study that students brought unauthorized materials including pocket guides and electronic devices into the examination hall to aid them to cheat.

Majority of the respondents agreed that students write examination answers on their palms, thighs and other body parts to enable them to cheat during examinations. This finding was consistent with that of Munachonga (2014) wherein her study, she indicated that students in Ghana perfected various forms of cheating in examinations where they smuggle foreign 
materials into examination halls, such as prepared notes and materials written on palms or thighs (especially for girls). For Clabaugh and Rozycki (2009), unsuspecting female students cross their legs and hide scribbled notes in between their legs and thighs and start reading the notes during the examination. They argued that female students use this method to cheat because they believe male invigilators will ignore them for fear of being labeled for sexual harassment and improper conduct. The findings again showed that the majority of respondents agreed that communication through asking for exams answers from colleagues is another form of cheating during examinations. This finding is corroborated by Munachonga (2014) who argued that students in Kenya were guilty of copying answers from other candidates and communicating via electronic gadgets during examinations. She indicated that students in Zambia whisper and also expose their work for others to copy.

\section{Conclusion}

The study shows that a significant number of the respondents have a fair idea about the acts of examination malpractice and do not think that one has to be academically dishonest and also indulge in such dishonest and unacceptable means to pass an examination. The results also show that an appreciable number of respondents know what constitutes examination malpractice. Furthermore, the study revealed that respondents have adequate knowledge of reasons why students cheat during examinations. One reason being the eagerness to pass the examinations by all means. Second is the inadequate preparation made for the examination by some students. Thirdly, some students are lazy and do not study well for the examination. Smuggling of foreign materials into the examination halls, writing of examination answers on the palms, thighs and other body parts, and communication through asking for examinations answers from colleagues are the most forms of malpractices students engage in. From the results, respondents agree that students can use digital wristwatches, and mobile phones to aid them copy during the examinations. In a nutshell, engaging in examination malpractice constitutes academic dishonesty.

\section{Recommendations}

To address the increasing number of examination malpractices, we propose the following to help maintain the credibility, confidence, and qualifications in the institution.

1) Since students have developed sophisticated and new forms of cheating during examination, we recommend the introduction of scanners and e-search software to help curb the new methods that students have adopted to cheat.

2) We also recommend to Management to review the offences, sanctions, and penalties on examination malpractices spelt out in the General and Examination Rules and Regulations to include the emerging new forms of malpractices.

3) The Guidance and Counseling Unit should intensify their engagements with students on preparation towards first university examinations, and also counsel them to refrain from involving themselves in actions that are contrary to the rules and regulations on examinations.

4) Students should be reminded from time to time to devote more of their time to their academic work and also have the belief that they can become successful without engaging in examination malpractices. 
5) Sitting arrangements should be spaced enough, so that it would be extremely difficult for students to see the writings of colleagues sitting beside them or in front of them, as well as prevent 'giraffing'.

6) Closed Circuit Television (CCTV) cameras should be installed in large examination halls, and also encourage invigilators to do thorough checks on students before allowing them into the examination halls.

7) To discourage all forms of cheating including minor offences, we recommend cancellation of students' papers and possibly, the rustication of the culprit for one academic year anytime a person is caught cheating.

8) To serve as a deterrent to students, we recommend that the University Statutes should be amended such that persons found culpable to have misconducted themselves would face expulsion from the University.

\section{References}

Achio, S., Ameko, E., Kutsanedzie, F., Alhassan, S., \& Ganaa, F. (2012). Concerns on Issues of Examination Malpractices: A Case Study of Accra Polytechnic. Natural \& Applied Sciences, 3(2), 145-154.

Asante-Kyei, K., \& Nduro, K. (2014). Inclining Factors towards Examination Malpractices among Students in Takoradi Polytechnic, Ghana. Journal of Education and Practice, 5(22), 66-73.

Aullo, P. A. (2004). An investigation into the Factors Contributing to Examination Irregularities in Kenya Certificate of Secondary Education (KCSE) in Nairobi Province. Nairobi, Kenya. A Masters Dissertation, University of Nairobi.

Balogun, J. O. (1999). Examination Malpractice and the Nigerian Society. The Jos Journal of Education, 4(1), 110-116.

Boakye, J. A. (2015, August 20). Examination Malpractice and Solutions: Opinions of Thursday. Ghana Web News.

Clabaugh, G. K., \& Rozycki, E. G. (2009). Preventing Cheating and Plagiarism. Orlando, PA: New Foundations Press.

Eckstein, M. A. (2003). Combating Academic Fraud: Towards a Culture of Integrity. Paris, France: International Institute for Educational Planning.

Edokpa. in Simwayi, M. (n.d.). The Role of the Law Enforcement Agencies in Combating Examination Malpractices in Zambia. Lusaka: Bank of Zambia, 1998.

Hang'andu, J. N. (2005). Legal Challenges of Examination Malpractices in Basic and Secondary Schools in Zambia. Lusaka. In Phiri, W. \& Nakamba, J. (2015). The Effect of Examination Malpractices (leakages) on Pupils' Academic Performance in Geography in selected Secondary Schools of Kitwe District, Copperbelt Province, Zambia. International Journal of Multidisciplinary Research and Development, 2(12), 324-331.

Hornby, A. S. (1995). Oxford Advanced Learners Dictionary (5th ed.), Oxford: Oxford University Press.

Khan, I., Khan, M. J., \& Khan, J. (2012). Teachers' Perception Regarding Malpractices used in Examinations in Urban areas of District Peshawar. University of Peshawar, Pakistan: 
Munich Personal RePEc Archive.

Kibler, W. L. (1993). Academic Dishonesty: A Student Development Dilemma. NAPSA Journal, 30(4), 252-267.

Kithuka, M. (2004). Educational Measurement and Evaluation. Egerton, Kenya: Egerton University Press.

Lawal, A. S., Abdulhakeem, I., \& Nenlat, R. (2015). Variable Factors on Examination Malpractices among Polytechnic Undergraduates. International Journal of Education and Evaluation, 1(8), 113-117.

Maheshwari, V. K. (2011). Malpractices in Education: The Termites Destroying the Educational Setup. Roorkee, India: Kanahiya Lal Dav PG College. Retrieved from http://www.vkmaheshwari.com/WP/?p=310.

Makaula, F. B. (2018). Perceived Causes and Methods of Examination Malpractice in the Malawian Education System. A Case Study of Secondary Schools in South East Education Division (SEED). Theses and Dissertations @ UNI 530.

Mashanyare, I., \& Chinamasa, E. (2014). School Examinations Leakage: Cases of Zimbabwe Schools Examinations Council. IOSR Journal of Humanities and Social Science, 19(4), 47-54. https://doi.org/10.9790/0837-19414754

McCabe, D. L. (2005). Presidents Report: The center for academic integrity. Durham, NC: Kenan Institute for Ethics, Duke University. In Makaula, F. B. (2018). Perceived Causes and Methods of Examination Malpractice in the Malawian Education System. A Case Study of Secondary Schools in South East Education Division (SEED). Theses and Dissertations @ UNI. 530.

Miranda, S. M. \& Freire C. (2011). Academic Dishonesty - Understanding how Undergraduate Students Think and Act. ISATT 2011 Conference, University of Minho, Braga, Portugal, 04-08 July, 2011.

Munachonga, M. (2014). An Ethical Evaluation of the Causes and Effects of Examination Malpractices in Zambia: Case Study of Selected Schools in Lusaka District. A Masters Dissertation. University of Zambia.

Ndifon, R. A., \& Cornelius-Ukpepi, B. U. (2014). Examination Malpractice in the Primary School: Problems and Prospects. International Journal of Humanities Social Sciences and Education, 1(9), 118-121.

Nnam, M. U., \& Inah, A. F. (2015). Empirical Investigation into the Causes, Forms and Consequences of Examination Malpractice in Nigerian Institutions of Higher Learning. International Journal of Novel Research in Humanity and Social Sciences, 2(1), 52-62.

Nwahunanya, C. (2004). Examination Malpractice: A Threat to the Credibility of Distance Education. In C. Nwahunanya (Ed.). Distance education at the crossroads in Nigeria.

Nwana, O. C. (2000). Aberrations in the Nigerian Education System in the State of Education in Nigeria. UNESCO Abuja.

Obudigha, W. (2010). Checking Examination Malpractice in Nigerian Schools. In Ndifon, R. A. \& Cornelius-Ukpepi, B. U. (2014). Examination Malpractice in the Primary School: Problems and Prospects. International Journal of Humanities Social Sciences and Education, 
l(9), 118-121.

Oduwaiye, R. O. (2014). Students' Perception of Factors and Solution to Examination Malpractices in Nigerian Universities: A Case Study of the University of Illorin. In Oko, S. U. \& Adie, R. I. (2016). Examination Malpractice: Causes, Effects and Possible Ways of Curbing the Menace. A Study of Cross River University of Technology. International Journal of Management Studies and Research, 4(1), 59-65.

Oko, S. U., \& Adie, R. I. (2016). Examination Malpractice: Causes, Effects and Possible Ways of Curbing the Menace. A Study of Cross River University of Technology. International Journal of Management Studies and Research, 4(1), 59-65. https://doi.org/10. 20431/2349-0349.0401006

Onah, O. A. (2010). The Counselling Implication of Examination Malpractice. Nigeria Journal of Science, Technology and Environmental Education, 3(1). In A. S. Lawal, A. S., Abdulhakeem, I. \& Nenlat, R. (2015). Variable Factors on Examination Malpractices among Polytechnic Undergraduates. International Journal of Education and Evaluation, 1(8), 113-117.

Petters, J. S., \& Okon, O. (2014). Students' Perception of Causes and Effects of Examination Malpractice in the Nigerian Educational System: The Way Forward for Quality Education. Procedia (Social and Behavioral Sciences), 114, 125-129. https://doi.org/10.1016/j.sbspro. 2013.12.671

Phiri, W., \& Nakamba, J. (2015). The Effect of Examination Malpractices (leakages) on Pupils' Academic Performance in Geography in selected Secondary Schools of Kitwe District, Copperbelt Province, Zambia. International Journal of Multidisciplinary Research and Development, 2(12), 324-331.

Suleman, Q., Gul, R., Ambrin, S., \& Kamran, F. (2015). Factors contributing to examination malpractices at secondary school level in Kohat Division. Pakistan. Journal of Education and Learning, 9(2), 165-182. https://doi.org/10.11591/edulearn.v9i2.1732

Tambawal, M. U. (2013). Examination Malpractices, Causes, Effects and Solutions. A Paper Presented at Stakeholders Forum on Raising Integrity in the Conduct of Examinations in the Nigerian Educational System. Held on February 7, 2013 at Usmanu Danfodiyo University, Sokoto.

Umaru, H. (2005). Examination Malpractices Challenges to Educational Development (WAKAJES), 2 (1 \& 2), 149-154. In Lawal, A. S., Abdulhakeem, I. \& Nenlat, R. (2015). Variable Factors on Examination Malpractices among Polytechnic Undergraduates. International Journal of Education and Evaluation, 1(8), 113-117.

University for Development Studies, Tamale, Academic Affairs Section (2018). Students Enrolment for the 2017/2018 Academic Year.

Uzochukwu, M. (2018). Examination Malpractice and Causes. Retrieved from https://hubpages.com/education/Examination-Malpractice-and-Causes 


\section{Copyright Disclaimer}

Copyright for this article is retained by the author(s), with first publication rights granted to the journal.

This is an open-access article distributed under the terms and conditions of the Creative Commons Attribution license (http://creativecommons.org/licenses/by/3.0/). 